\title{
36. REGIONAL SYNTHESES, LINE ISLANDS CHAIN, TUAMOTU ISLAND CHAIN, AND MANIHIKI PLATEAU, CENTRAL PACIFIC OCEAN
}

\author{
Everett D. Jackson, U.S. Geological Survey, Menlo Park, California \\ and \\ Seymour O. Schlanger, University of California at Riverside, Riverside, California
}

\section{INTRODUCTION}

On Leg 33 Glomar Challenger ventured in an area of the central and south-central Pacific heretofore little explored by means of drilling. The entire region, encompassing the Line Islands, the Manihiki Plateau, and the northern Tuamotu Islands proved to be geologically extremely complex. Any progress we have made in contributing to our understanding of it has been due, in large part, to the pre-Leg 33 and post-Leg 33 bathymetry, acoustic profiling, and dredging done by E. L. Winterer, J.W. Hawkins, Jr., and their students at Scripps Institution of Oceanography. Three papers of this volume, as well as the revised bathymetry of the Line Islands (Winterer, this volume), are due to their work. Leg 33 benefited greatly also from previous results of DSDP Legs $6,7,8,9,17$, and 32, which are frequently referred to throughout this volume.

The following summaries incorporate the data and interpretations of the previous chapters of this volume, more or less chronologically. Inasmuch as the deepest rocks encountered in the area are basaltic, and inasmuch as several periods of volcanism have occurred, it is important to classify the products of volcanism. It is apparent that at least three compositionally distinct categories of basaltic rocks have been drilled or dredged in the area of the central Pacific basin investigated during Leg 33 (Jackson et al., this volume; Clague, this volume; Natland, this volume): (1) basalts whose bulk chemical composition and mineralogy resemble those forming at mid-oceanic ridges; these are thought to represent oceanic crust, and, in the following discussion, are referred to as oceanic ridge tholeiites; (2) basalts whose bulk chemical composition and mineralogy resemble those of linear island chains; these form as large, generally aligned edifices atop and later than the oceanic crust, and in the discussion below are referred to as oceanic island basalts; (3) basalts whose bulk chemical composition and mineralogy resemble those of African rift zones or the post-erosional undersaturated basanites and nephelinites of the Hawaiian, Samoan, or Society chains; these are thought to be formed by epeirogenic uplift of chains and seamounts at some time after their formation, and in the discussion below are referred to as post-edifice basalts. Because these three basaltic types crystallized in a temporal sequence, their positions and ages give important clues to the volcanic "stratigraphy" of the central Pacific basin and are as useful as the sedimentary record in discussing the general geology of the area.

In spite of the information at hand, serious questions remain about the origin of this part of the Pacific Basin; the following summaries perhaps raise as many questions as they answer, but should prove of value in pointing out areas of further research.

\section{LINE ISLANDS CHAIN}

\section{Oceanic Crust}

The area northwest and southwest of the present position of the Line Islands contains the Hawaiian and Phoenix magnetic lineaments of Vogt et al. (1971), Larson and Pitman (1972), Larson, Moberly, et al. (1974), Baldwin et al. (1975), and Winterer (this volume). The youngest age of these lineaments is in some doubt; estimates range between 110 and 130 m.y., but the most reasonable age for the reversed anomaly M-1 is likely to be between 119 and 127 m.y. (Baldwin et al., 1975). To the north and west of the Line Islands, no such lineations are known with certainty west of anomaly 32 of Heirtzler et al. (1968). As pointed out by Winterer (this volume) volcanic rocks younger than the oceanic crust upon which they rest, which form the Line Islands and a part of the Mid-Pacific Mountains, cover the critical portion of the bight between the Phoenix and Hawaiian anomalies. It may be added that these younger volcanic rocks obscure possible extensions of the Molokai and Clarion fracture zones in the same area. Thus, a great deal of speculation is necessary to reconstruct the evolution of the Pacific, Phoenix, and Farallon plates during the interval from about 150-80 m.y. (Larson and Chase, 1972; Hilde et al., 1974; Clague, 1974; Winterer, this volume).

Inasmuch as at least three distinct types of basaltic rocks are known in the area surrounding the Line Islands and the Phoenix and Hawaiian anomalies, it seems fruitful to review their distribution and ages. See Table 1 and Figure 1 (in pocket at back of volume). The three types of basaltic rocks present in the area are: oceanic ridge tholeiites (ORB of Table 1); oceanic island basalts (OIB of Table 1); and post-edifice basanites and nephelinites, for the most part containing primary amphibole or biotite (PEB of Table 1). A number of petrographic and chemical criteria are available to distinguish these three groups; they are summarized by Jackson et al. (this volume), Clague (this volume), Natland (this volume), and Jackson (in press).

Oceanic ridge tholeiites were drilled at Sites 307, 169, 167, 166, and 164 (see Figure 1). Basalt was also drilled at Site 66, but to our knowledge, its type has not been established. The oceanic ridge tholeiites drilled at Sites 307,167 , and 166 are of ages appropriate to those of the Hawaiian and Phoenix magnetic lineations. The oceanic ridge tholeiites drilled at Site 169 , however, are too 
TABLE 1

Data on Basalts Drilled or Dredged in the General Area of the Line Islands

\begin{tabular}{|c|c|c|c|c|c|c|c|}
\hline Site or Dredge & Core & Location & $\begin{array}{l}\text { Character } \\
\text { of Basalt }\end{array}$ & $\begin{array}{c}\text { Age } \\
\text { (m.y.B.P.) }\end{array}$ & Source & $\begin{array}{c}\text { Type of } \\
\text { Basalt }\end{array}$ & Source \\
\hline DSDP Site 45.1 & 3 & $\begin{array}{l}24^{\circ} 16^{\prime} \mathrm{N} \\
178^{\circ} 30.5^{\prime} \mathrm{W}\end{array}$ & No basalt reached & $>76-78$ & Fischer et al. (1971) & - & - \\
\hline DSDP Site 46.0 & 2 & $\begin{array}{r}27^{\circ} 53^{\prime} \mathrm{N} \\
171^{\circ} 26^{\prime} \mathrm{E}\end{array}$ & No basalt reached & $>70$ & Fischer et al. (1971) & - & - \\
\hline DSDP Site 66.0 & 10,11 & $\begin{array}{l}02^{\circ} 23.5^{\prime} \mathrm{N} \\
166^{\circ} 07^{\prime} \mathrm{W}\end{array}$ & Basalt & $\begin{array}{l}\geq 87-100 \\
>50\end{array}$ & $\begin{array}{l}\text { Winterer, Riedel, et al. (1971) } \\
\text { Ozima et al. (1973) }\end{array}$ & Unknown & Moberly and Heath (1971) \\
\hline \multirow[t]{2}{*}{ DSDP Site 164} & 27 & $\begin{array}{r}13^{\circ} 12^{\prime} \mathrm{N} \\
161^{\circ} 31^{\prime} \mathrm{W}\end{array}$ & Basalt flows & $>100-116$ & Winterer, Ewing, et al. (1973) & $\mathrm{ORB}^{\mathrm{a}}$ & Bass et al. (1973) \\
\hline & 28 & $\begin{array}{r}13^{\circ} 12^{\prime} \mathrm{N} \\
161^{\circ} 31^{\prime} \mathrm{W}\end{array}$ & Basalt flows & $>52 \pm 5$ & Ozima and Saito (1974) & ORB & Bass et al. (1973) \\
\hline \multirow[t]{3}{*}{ DSDP Site 165} & $23 \mathrm{~A}, 24 \mathrm{~A}$ & $\begin{array}{c}08^{\circ} 11^{\prime} \mathrm{N} \\
164^{\circ} 51.5^{\prime} \mathrm{W}\end{array}$ & Fragmental basalt & $\begin{array}{r}\geqslant 76-80 \\
86-91\end{array}$ & $\begin{array}{l}\text { Winterer, Ewing, et al. (1973) } \\
\text { Lanphere and Dalrymple (this } \\
\text { volume) }\end{array}$ & Unknown & Bass et al. (1973) \\
\hline & $26 \mathrm{~A}$ & $\begin{array}{l}08^{\circ} 11^{\prime} \mathrm{N} \\
164^{\circ} 51.5^{\prime} \mathrm{W}\end{array}$ & Massive basalt & $89-95$ & $\begin{array}{l}\text { Lanphere and Dalrymple (this } \\
\text { volume) }\end{array}$ & $\begin{array}{l}\mathrm{OIB}^{\mathrm{b}} \\
\text { PEB }^{\mathrm{c}}\end{array}$ & $\begin{array}{l}\text { Bass et al. (1973) } \\
\text { see text }\end{array}$ \\
\hline & $27 \mathrm{~A}$ & $\begin{array}{l}08^{\circ} 11^{\prime} \mathrm{N} \\
164^{\circ} 51.5^{\prime} \mathrm{N}\end{array}$ & Massive basalt & $\begin{aligned} & \geqslant 85 \\
& \geqslant 79-83 \\
& 93-100\end{aligned}$ & $\begin{array}{l}\text { Winterer, Ewing, et al. (1973) } \\
\text { Part I (this volume) } \\
\text { Lanphere and Dalrymple (this } \\
\text { volume) }\end{array}$ & $\begin{array}{l}\text { OIB } \\
\text { PEB }\end{array}$ & $\begin{array}{l}\text { Bass et al. (1973) } \\
\text { See text }\end{array}$ \\
\hline DSDP Site 166 & 29 & $\begin{array}{r}03^{\circ} 46^{\prime} \mathrm{N} \\
175^{\circ} 05^{\prime} \mathrm{W}\end{array}$ & Extrusive basalt & $\geqslant 120$ & Winterer, Ewing, et al. (1973) & ORB & Bass et al. (1973) \\
\hline \multirow[t]{2}{*}{ DSDP Site 167} & 94 & $\begin{array}{l}07^{\circ} 04^{\prime} \mathrm{N} \\
176^{\circ} 49.5^{\prime} \mathrm{W}\end{array}$ & Extrusive basalt & $\geqslant 130$ & Winterer, Ewing, et al. (1973) & ORB? & Bass et al. (1973) \\
\hline & 95 & $\begin{array}{l}07^{\circ} 04^{\prime} \mathrm{N} \\
176^{\circ} 49.5^{\prime} \mathrm{W}\end{array}$ & Extrusive basalt & $169 ?$ & Ozima and Saito (1974) & ORB? & Bass et al. (1973) \\
\hline \multirow[t]{2}{*}{ DSDP Site 169} & 5,6 & $\begin{array}{r}10^{\circ} 40^{\prime} \mathrm{N} \\
173^{\circ} 33^{\prime} \mathrm{E}\end{array}$ & Diabase sill & $\begin{aligned} & >76-80 \\
& >16\end{aligned}$ & $\begin{array}{l}\text { Winterer, Ewing, et al. (1973) } \\
\text { Ozima et al. (1973) }\end{array}$ & $\begin{array}{l}\text { ORB? } \\
\text { PEB }\end{array}$ & $\begin{array}{l}\text { Bass et al. (1973) } \\
\text { Myers et al. (1975) }\end{array}$ \\
\hline & 11,12 & $\begin{array}{r}10^{\circ} 40^{\prime} \mathrm{N} \\
173^{\circ} 33^{\prime} \mathrm{E}\end{array}$ & Extrusive basalt & $\geqslant 100-102$ & Winterer, Ewing, et al. (1973) & ORB? & Bass et al. (1973) \\
\hline \multirow[t]{2}{*}{ DSDP Site 170} & $10,11,12$ & $\begin{array}{r}11^{\circ} 48^{\prime} \mathrm{N} \\
177^{\circ} 37^{\prime} \mathrm{E}\end{array}$ & Basalt gravel & $>76-80$ & Winterer, Ewing, et al. (1973) & ОІв & $\begin{array}{l}\text { Bass et al. (1973) } \\
\text { see text }\end{array}$ \\
\hline & 16 & $\begin{array}{r}11^{\circ} 48^{\prime} \mathrm{N} \\
177^{\circ} 37^{\prime} \mathrm{E}\end{array}$ & Basalt flow? & $>100-103$ & Winterer, Ewing, et al. (1973) & $\begin{array}{l}\text { OIB } \\
\text { PEB? }\end{array}$ & $\begin{array}{l}\text { Bass et al. (1973) } \\
\text { see text }\end{array}$ \\
\hline \multirow[t]{2}{*}{ DSDP Site 171} & 27 & $\begin{array}{l}19^{\circ} 08^{\prime} \mathrm{N} \\
169^{\circ} 27.5^{\prime} \mathrm{W}\end{array}$ & Basalt flow & $\geqslant 87-91$ & Winterer, Ewing, et al. (1973) & OIB & Bass et al. (1973) \\
\hline & 33 & $\begin{array}{l}19^{\circ} 08^{\prime} \mathrm{N} \\
169^{\circ} 27.5^{\prime} \mathrm{W}\end{array}$ & Basalt flow & $\geqslant 110$ ? & Winterer, Ewing, et al. (1973) & OIB & Bass et al. (1973) \\
\hline DSDP Site 307 & 13 & $\begin{array}{r}28^{\circ} 35.5^{\prime} \mathrm{N} \\
161^{\circ} 00.5^{\prime} \mathrm{E}\end{array}$ & Basalt flow & $\geqslant 130-136$ & Larson, Moberly, et al. (1975) & ORB & Marshall (1975) \\
\hline DSDP Site 313 & 43 & $\begin{array}{r}20^{\circ} 11^{\prime} \mathrm{N} \\
170^{\circ} 57^{\prime} \mathrm{W}\end{array}$ & Basalt flow & $>75-80$ & Larson, Moberly, et al. (1975) & PEB & Marshall (1975) \\
\hline DSDP Site 315 & $\begin{array}{l}30 \mathrm{~A}, \\
31 \mathrm{~A}, \\
32 \mathrm{~A}, \\
33 \mathrm{~A}, \\
34 \mathrm{~A},\end{array}$ & $\begin{array}{l}04^{\circ} 10^{\prime} \mathrm{N} \\
158^{\circ} 31.5^{\prime} \mathrm{W}\end{array}$ & Basalt flows & $\begin{aligned} & \geqslant 85 \\
91.2 & \pm 2.7 \\
& \geqslant 85-92\end{aligned}$ & $\begin{array}{l}\text { Part I (this volume) } \\
\text { Lanphere and Dalrymple } \\
\text { (this volume) } \\
\text { (this volume) }\end{array}$ & $\begin{array}{l}\text { OIB } \\
\text { OIB }\end{array}$ & $\begin{array}{l}\text { Part I (this volume) } \\
\text { Jackson et al. (this } \\
\text { volume) } \\
\text { see text }\end{array}$ \\
\hline DSDP Site 316 & 28 & $\begin{array}{r}00^{\circ} 06^{\prime} \mathrm{N} \\
157^{\circ} 08^{\prime} \mathrm{W}\end{array}$ & Basaltic breccia & $>81-83$ & Part I (this volume) & OIB & $\begin{array}{l}\text { Jackson et al. (this } \\
\text { volume) }\end{array}$ \\
\hline Dredge 118D & & $\begin{array}{r}02^{\circ} 45^{\prime} \mathrm{N} \\
165^{\circ} 01^{\prime} \mathrm{W}\end{array}$ & $\begin{array}{l}\text { Clast in hyalo- } \\
\text { clastite breccia }\end{array}$ & ? & - & OIB & Natland (this volume) \\
\hline Dredge 119D & & $\begin{array}{r}02^{\circ} 45^{\prime} \mathrm{N} \\
165^{\circ} 01^{\prime} \mathrm{W}\end{array}$ & Flow & ? & - & OIB & Natland (this volume) \\
\hline Dredge 122D & & $\begin{array}{r}05^{\circ} 14^{\prime} \mathrm{N} \\
161^{\circ} 30^{\prime} \mathrm{W}\end{array}$ & $\begin{array}{l}\text { Clast in hyalo- } \\
\text { clastite breccia }\end{array}$ & ? & - & PEB & Natland (this volume) \\
\hline Dredge 123D & & $\begin{array}{l}05^{\circ} 50^{\prime} \mathrm{N} \\
160^{\circ} 45^{\prime} \mathrm{W}\end{array}$ & Broken pillow & ? & - & $\begin{array}{l}\text { OIB? } \\
\text { PEB? }\end{array}$ & $\begin{array}{l}\text { Natland (this volume) } \\
\text { see text }\end{array}$ \\
\hline Dredge 128D & & $\begin{array}{r}09^{\circ} 15^{\prime} \mathrm{N} \\
158^{\circ} 45^{\prime} \mathrm{W}\end{array}$ & Isolated pillows & $?$ & & OIB & Natland (this volume) \\
\hline Dredge 129D & & $\begin{array}{r}09^{\circ} 20^{\prime} \mathrm{N} \\
163^{\circ} 10^{\prime} \mathrm{W}\end{array}$ & $\begin{array}{l}\text { Clast in hyalo- } \\
\text { clastite breccia }\end{array}$ & ? & & $\begin{array}{l}\text { PEB } \\
\text { OIB }\end{array}$ & Natland (this volume) \\
\hline Dredge 130D & & $\begin{array}{r}08^{\circ} 20^{\prime} \mathrm{N} \\
164^{\circ} 22^{\prime} \mathrm{W}\end{array}$ & $\begin{array}{l}\text { Clasts in } \\
\text { aquagene tuff }\end{array}$ & $?$ & & $\begin{array}{l}\text { OIB } \\
\text { PEB }\end{array}$ & $\begin{array}{l}\text { Natland (this volume) } \\
\text { see text }\end{array}$ \\
\hline
\end{tabular}


TABLE 1 - Continued

\begin{tabular}{|c|c|c|c|c|c|c|c|}
\hline Site or Dredge & Core & Location & $\begin{array}{l}\text { Character } \\
\text { of Basalt }\end{array}$ & $\begin{array}{c}\text { Age } \\
\text { (m.y.B.P.) }\end{array}$ & Source & $\begin{array}{l}\text { Type of } \\
\text { Basalt }\end{array}$ & Source \\
\hline Dredge 1331) & & $\begin{array}{r}12^{\circ} 04^{\prime} \mathrm{N} \\
165^{\circ} 50^{\prime} \mathrm{W}\end{array}$ & $\begin{array}{l}\text { Clasts in aquagene } \\
\text { tuff }\end{array}$ & 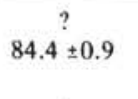 & Ozima and Saito (1974) & $\begin{array}{l}\text { OIB } \\
\text { OIB } \\
\text { PEB? }\end{array}$ & $\begin{array}{l}\text { Natland (this volume) } \\
\text { Natland (this volume) } \\
\text { see text }\end{array}$ \\
\hline Dredge 134D & & $\begin{array}{r}10^{\circ} 18^{\prime} \mathrm{N} \\
168^{\circ} 00^{\prime} \mathrm{W}\end{array}$ & $\begin{array}{l}\text { Aquagene tuff and } \\
\text { segregations in tuff }\end{array}$ & $?$ & & PEB & Natland (this volume) \\
\hline Dredge 137D & & $\begin{array}{r}14^{\circ} 27^{\prime} \mathrm{N} \\
168^{\circ} 59^{\prime} \mathrm{W}\end{array}$ & $\begin{array}{l}\text { Clasts in pyroclastic } \\
\text { breccia and lime- } \\
\text { stone }\end{array}$ & $?$ & - & OIB & Natland (this volume) \\
\hline Dredge $138 \mathrm{D}$ & & $\begin{array}{r}15^{\circ} 39^{\prime} \mathrm{N} \\
169^{\circ} 18^{\prime} \mathrm{W}\end{array}$ & $\begin{array}{l}\text { Clast in aquagene } \\
\text { tuff }\end{array}$ & $?$ & - & PEB & Natland (this volume) \\
\hline Dredge 142D & & $\begin{array}{r}18^{\circ} 00^{\prime} \mathrm{N} \\
169^{\circ} 05^{\prime} \mathrm{W}\end{array}$ & Probable flow & $128 \pm 5.0$ & Ozima and Saito (1974) & OIB & Natland (this volume) \\
\hline Dredge 144D & & $\begin{array}{r}21^{\circ} 32^{\prime} \mathrm{N} \\
167^{\circ} 56^{\prime} \mathrm{W}\end{array}$ & Flow material & $>61.3$ & Natland (this volume) & $\begin{array}{l}\text { OIB } \\
\text { OIB }\end{array}$ & $\begin{array}{l}\text { Heezen et al. (1973) } \\
\text { Natland (this volume) }\end{array}$ \\
\hline Dredge AV-19 & & $\begin{array}{r}21^{\circ} 09^{\prime} \mathrm{N} \\
163^{\circ} 22^{\prime} \mathrm{E}\end{array}$ & $\begin{array}{l}\text { Blocks in chalk } \\
\text { cobbles in chalk }\end{array}$ & $?$ & & $\begin{array}{l}\text { OIB } \\
\text { OIB }\end{array}$ & $\begin{array}{l}\text { Heezen et al. (1973) } \\
\text { Natland (this volume) }\end{array}$ \\
\hline Dredge AV-21 & & $\begin{array}{c}21^{\circ} 43^{\prime} \mathrm{N} \\
161^{\circ} 52.5^{\prime} \mathrm{E}\end{array}$ & $\begin{array}{l}\text { Blocks in chalk } \\
\text { isolated pillow } \\
\text { breccia }\end{array}$ & $?$ & & $\begin{array}{l}\text { PEB } \\
\text { PEB }\end{array}$ & $\begin{array}{l}\text { Heezen et al. (1973) } \\
\text { Natland (this volume) }\end{array}$ \\
\hline Dredge AV-25, 27 & & $\begin{array}{r}24^{\circ} 05^{\prime} \mathrm{N} \\
159^{\circ} 27^{\prime} \mathrm{E}\end{array}$ & $?$ & $?$ & Heezen et al. (1973) & $\begin{array}{l}\text { PEB } \\
\text { PEB }\end{array}$ & $\begin{array}{l}\text { Heezen et al. (1973) } \\
\text { Natland (this volume) }\end{array}$ \\
\hline
\end{tabular}

${ }^{\mathrm{a}} \mathrm{ORB}$ is oceanic ridge tholeiite.

${ }^{\mathrm{b}} \mathrm{OIB}$ is oceanic island tholeiite, some alkalic basalt, hawaiite, mugearite, or trachyte.

'PEB is post-edifice basalt, commonly undersaturated and commonly containing primary amphibole or biotite or both.

young to have formed in the interior of the bight, and either their composition is inappropriate (a problem considered by Bass et al., 1973), or their extrapolated age (Winterer, Ewing, et al., 1973) is too young for the position now occupied by these rocks. The oceanic ridge tholeiite at Site 164 lies east of the 110 m.y. position of the Pacific-Farallon ridge proposed by Winterer (this volume); he therefore proposed a 105 m.y. eastward jump in that ridge to account for the age and position of the Site 164 rocks. It seems more likely, based on other data discussed below that such a ridge jump did not occur, but rather that the block between the Clarion and Molokai fracture zones was already in existence by 110 m.y. and that the active Pacific-Farallon Ridge segment between these fracture zones had already advanced to the east by that time (Malahoff et al., 1966). The only dated rocks south of the oceanic-island-type rocks of Hawaiian Islands are from three seamounts (Dymond and Windom, 1968). Biotite and hornblende separates from two of these seamounts gave ages of 85-90 m.y., but the very presence of these minerals as phenocrysts in the lavas suggests they are basalts of post-edifice type. A third whole-rock age on an alkalic basalt (also suspected of being younger than oceanic crust in that area) yielded a value of only $0.7 \pm 0.05$ m.y. (Dymond and Windom, 1968). In effect, no reliable age of the oceanic crust in this area exists. If Winterer's 110 to 105 m.y. ridge jump did occur, one would expect abandoned Cretaceous anomalies (in the portion of the Farallon plate incorporated into the Pacific plate by the jump) to be present in the area immediately west of the Line Islands, and these anomalies should still be present (see Winterer, this volume, fig. 15). No such anomalies have been reported south and east of Necker Ridge.

\section{Edifices of the Line Islands Chain}

Basaltic rocks of the oceanic island edifice type are scattered over much of the area from near Wake Island through Site 170 and are heavily concentrated along the Line Islands (see Figure 1). They are also probably densely represented in the Mid-Pacific Mountains, but the petrology of the basalts at the many dredge localities reported by Natland in Heezen et al. (1973) is not sufficiently detailed to plot them on Figure 1 with any assurance. All occurrences of oceanic island basalts, with the exception of "oceanic island mugearites, and basalts" at Site 170 of Bass et al. (1973), are associated with seamounts or subaerial edifices. Unfortunately, many are undated. The thick clustering of these rocks along the Line Islands (see Natland, this volume), including their presence at Site 315 (see Jackson et al., this volume), suggests that the Line Islands seamount chain is basically built of the same materials as the Samoan and Hawaiian chains (Natland, this volume; Jackson et al., this volume). Only two rocks certain to be of the oceanic island basalt type in the Line Islands chain are presently reliably dated by radiometric methods: a trachyte from dredge 7 Tow $6-142 \mathrm{D}$, at $128 \pm 5$ m.y. 
(Ozima and Saito, 1974; Natland, this volume) and rocks transitional between oceanic island tholeiite and alkalic basalt drilled at Site 315 , at $91.2 \pm 2.7$ m.y. (Lanphere and Dalrymple, this volume; Jackson et al., this volume). A third rock, described as a picritic alkalic olivine basalt (Natland, this volume), but not analyzed, was recovered from dredge 7 Tow 6-133D, and was dated by Ozima and Saito (1974) at $84.4 \pm 0.9$ m.y. Natland (this volume) indicated that this rock is of the oceanic island type, but Jackson (in press) has pointed out that many of the Hawaiian pre-erosional and posterosional alkalic basalts are texturally and compositionally identical, although any alkalic basalt with as much as $5 \%$ normative nepheline is probably of postedifice origin. In addition to the picritic alkalic olivine basalt from dredge 133, sample 123-15 (Natland, this volume), which contains relatively high $\mathrm{K}_{2} \mathrm{O}$ and $1 \%-5 \%$ normative nepheline, is suspect of being a post-edifice basalt, as is sample $130-2$, which contains between $7 \%$ and $11 \%$ normative nepheline. If the seamount from which dredge 133 was recovered proves to be related to a Line Islands edifice at a location north of Site 165, and if Ozima and Saito's age data are accurate, construction of the Line Islands edifices moved southward from the location of dredge 142D toward the location of $133 \mathrm{D}$, but was simultaneously moving northward from Site 315 toward the location of dredge 133D (see Table 1 and Figure 1). A much simpler model can be constructed by assuming that the dated rock from Natland's (this volume) dredge 133D is indeed a post-edifice basalt.

In this event, the rocks from dredge 142D and the transitional basalt from Site 315 yield what appear to be reliable ages of $128 \pm 5.0$ m.y. and $91.2 \pm 2.7$ m.y., respectively. The ages, and the distance between the localities, assuming an average direction for the chain of $\mathrm{S} 37.5^{\circ} \mathrm{E}$, yield an apparent rate of volcanic progression of $5.2 \mathrm{~cm} / \mathrm{yr}$, although this rate is slow compared to long-term propagation rates of other chains, and subject to the irregularities of detailed volcanic propagation pointed out by Jackson (in press). Extrapolation of rates of volcanic progression is a very tenuous matter; but it is interesting to speculate that if that rate were constant in the Line Islands, the age of oceanic island basaltic basement at Site 165A would be about 104 m.y., and the true edifice age at Site 316 would be about 82.5 m.y., very close to our original estimate of 81-83 m.y.

It should be pointed out that if Winterer's (this volume) reconstruction of the position of the 110 m.y. Pacific-Farallon Ridge is correct, then the trachyte dated by Ozima and Saito (1974) is considerably older than the crust upon which it was collected, and its age could be incorrect. Conversely, the Molokai-Clarion fracture system could have been in operation by 110 m.y., and that portion of the Pacific-Farallon Ridge could have been located well east of the Line Islands by 128 m.y.

\section{Post-edifice Basalts}

Natland (this volume) has pointed out that potassic basanites and nephelinites appear consistently in dredge hauls from the Line Islands, but also occur far to the northwest near Wake Island (see Figure 1). Natland (this volume) and Jackson et al. (this volume) have pointed out that Bass et al. (1973) have misleadingly identified similar rocks from Site 165 as hawaiites and mugearites, although they contain considerable primary amphibole and biotite. Reexamination of the upper "diabase" from Cores 5 and 6 at Site 169 by Myers et al. (1975) shows it to be an alkalic basalt with primary amphibole, and we would classify it as probably a postedifice basalt. Winterer, Ewing, et al. (1973) give an extrapolated age for this unit of $\geq 76-80$ m.y. The description of the rocks at Site 170 (Bass et al., 1973) shows that the rocks in Core 10 , dated at $\geq 76-80$ m.y., contain mica as a major constituent and are probably of the postedifice-type basalts, whereas those in Core 16 contain $6 \%-10 \%$ normative nepheline, and, although highly altered, are suspect of being basalts of the same type. Marshall (1975) reports undersaturated rocks from Site 313 dated at $\geq 75-80$ m.y. that contain primary biotite and amphibole. It would appear that potassic basanites and nephelinites occur over a considerable area of the central Pacific. Natland (this volume) has noted the similarity of some of these rocks to those of African rift zones, but has also noted their resemblance to Hawaiian post-erosional basalts (Macdonald and Katsura, 1964), and to Samoan post-erosional basalts (Hawkins and Natland, 1975; Natland and Clague, 1975). They also resemble the post-erosional lavas of Tahiti (Denoufbourg, 1965; McBirney and Aoki, 1968). Jackson (in press) makes the point that lavas ranging from alkalic basalt to basalt with strongly undersaturated composition may occur on preexisting seamounts or islands whenever such edifices are subjected to epeirogenic uplift, at any time after the formation of the original edifice. The presence of these potassic undersaturated rocks may be due, as Natland (this volume) argues, to incipient rifting and uplift along the Line Cross direction. Their presence at Site 313, on the other hand, may argue for a period of much broader uplift that included the Line Cross area but that extended from Sites 169 and 170 , along the preexisting Line Islands, to the eastern Mid-Pacific Mountains. Another uplift, of perhaps a different age, may account for the presence of these rocks in the vicinity of Wake Island. From available age data, we might suggest such a period of epeirogeny in the area from the Wake Guyots to as far east as Site 170, that occurred at some time $\geq 100-103 \mathrm{~m} . \mathrm{y}$. The upper basalts at Sites 169 and 170 may then record a second epeirogenic event that occurred as far east as the Line Islands at 80-85 m.y.

The sample of picritic alkali olivine basalt from dredge $133 \mathrm{D}$, as previously discussed, has been radiometrically dated as $84.4 \pm 0.9$ m.y. old (Saito and Ozima, 1974; Natland, this volume). If this rock has a postedifice relationship to the original Line Islands edifices, then its age is coincidental with four other samples of potassic basanite or nephelinite that have been dated by extrapolation from overlying fossiliferous sediments at Sites 165, 169, 170, and 313. van Andel (1972) and van Andel and Bukry (1973) point out the pitfalls of extrapolated ages, and Lanphere and Dalrymple (this volume) specifically cite extreme but possible extrapolations for the potassic basanites at Site 165 . 
Nevertheless, extrapolation is the only method presently available for dating these rocks, which apparently overlie oceanic island basalts at Site 313 (Larson, Moberly et al., 1975), at Site 165, and which apparently overlie either oceanic island or earlier post-edifice basalts at Site 170 and overlie oceanic ridge basalts at Site 169 (Winterer, Ewing, et al., 1973). By this method the potassic rocks are best dated at $\geq 75-80$ m.y. at Site 313, at $\geq 79-83$ m.y. at Site $165 \mathrm{~A}$ (see below), and at $\geq 76-80$ m.y. at Sites 169 and 170.

We believe that these rocks are post-edifice volcanics generated by an epeirogenic uplift of the area between Site 169, the Line Islands, and at least the eastern MidPacific Mountains in the period 80-85 m.y. Beneath the post-edifice basalts at Sites 313 and 165A one would expect older basalts of the oceanic island type to be present, and, in the case of $165 \mathrm{~A}$, these may be as old as 104 m.y., if our extrapolation of the rate of volcanic chain progression is correct. If the potassic basanites at Site 165 prove to be older than 85 m.y., then one must invoke two periods of post-edifice volcanism along the Line Islands chain, the younger of which was accompanied by regional epeirogeny.

\section{Regional Synthesis of the Line Islands}

The stratigraphy of the Line Islands is summarized in Figure 2 (see also Cook, this volume). Shipboard scientists on Leg 33 divided the post-basalt sections drilled at Sites 315 and 316 into five lithologic units; Site 165 (Winterer, Ewing, et al., 1973) was reinterpreted in terms of Leg 33 units for the purposes of comparison. The units appear to be diachronous along the southern

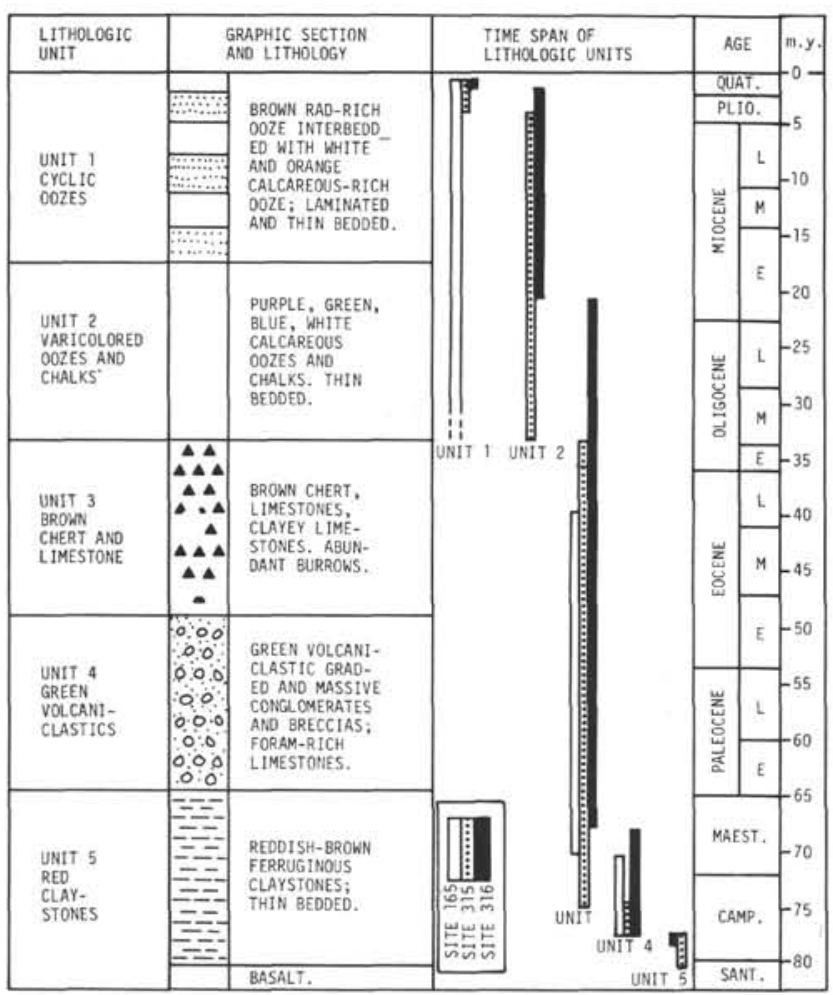

Figure 2. Comparison of time spans of lithologic units at Sites 165, 315, and 316 (after Cook this volume).
Line Islands chain, although the original time span of each unit may have been locally obscured by the development of hiatuses. For example, at Site 165 Unit 2 of Figure 2 was not found; almost the entire post-early Miocene and Pliocene section was eroded prior to Quaternary time.

The sedimentary history of the region begins with the development of Unit 5, which consists of Fe- and Ti-rich claystones. These sediments superficially resemble the $\mathrm{Fe}-$ and $\mathrm{Ti}$-rich basal sediments associated with spreading oceanic ridges. However, their chemistry differs not only from spreading ridge basal sediments but also normal Pacific pelagic clays (Jenkyns and Hardy, this volume); the unit more closely resembles the underlying basalts, the implication being that Unit 5 was essentially derived from the submarine weathering of the basaltic material that formed the foundation of the Line Islands chain. Radiolarians, heavily infilled with silica, are the only fossils found-these radiolarians are common in pelagic interbeds associated with volcaniclastic sections in the unit.

Unit 4, of volcaniclastic origin (Kelts and McKenzie, this volume), consists largely of altered volcanic glass, feldspars-many of which are K-feldspars of diagenetic origin-mafic minerals, and clays formed by the alteration of volcanogenic material. Hyaloclastic textures, graded bedding, and current structures are common. The unit accumulated by submarine debris and turbidity flows that moved down the sides of nearby edifices or linear ridges (Cook et al., this volume). The basal 100 meters of the unit are particularly lacking in fossil material and $\mathrm{CaCO}_{3}$. The upper parts are rich in redeposited skeletal debris (Beckmann, this volume; see Winterer, Ewing, et al., 1973, for descriptions of Site $165)$. Broken and abraded tests of large foraminifers such as Pseudoorbitoides, Asterorbis, and Sulcoperculina are common along with fragments of coralline algae and rudistids. The assemblage is diagnostic of shallow carbonate banks within the photic zone growing less than 100 meters below the sea surface.

Units 3,2 , and 1 that overlie the volcanic-rich section are dominantly composed of pelagic carbonates. In these units redeposited material is common, and includes Cretaceous shallow-water debris like that described above within pelagic carbonates of Oligocene age. Numerous hiatuses in the sections are documented in the individual site reports.

The stratigraphic and sedimentologic data relevant to the history of the development of the Line Islands chain can be summarized as follows:

a) Flow volcanism of the oceanic island basaltic edifice type had progressively ceased along the segment of the Line Islands chain spanned by Sites 165, 315, and 316 by $105-80$ m.y., in Santonian-Cenomanian time. Larger edifices were probably being built near the drilled sites, but vesicles in the basalts cored at Site 315 suggest water depths of at least $2-3 \mathrm{~km}$ at that location (Jackson et al., this volume). The lack of redeposited shallow-water skeletal debris and calcareous planktonic elements in the radiolarian-bearing interbeds between turbidites in Unit 4 also suggest water depths greater than $2-3 \mathrm{~km}$. 
b) By Maestrichtian-Campanian time, approximately 70 to 80 m.y., carbonate banks had become established on the tops of edifices along the chain. Foraminifers, algae, and molluscs swept from these banks became important contributors to the debris and turbidity flows that were moving large amounts of clastic volcanic debris down the edifice and ridge slopes.

c) By the end of Maestrichtian time, approximately 65 m.y., the sedimentological influence of shallower parts of the Line Islands chain or ridge had waned at the sites drilled, and pelagic sedimentation dominated.

The hiatuses in the drilled sections, the abundant evidence of truncated units seen on profiler records (Winterer, this volume; Schlanger and Winterer, this volume), and deep channeling and scouring in the archipelagic apron around the island chain, indicate that the Line Islands chain, as a geomorphic province, has long been affected by the motion of bottom waters and has perhaps long served as a partial barrier to the motion of bottom waters from the Central Basin eastwards towards the Hawaiian Islands.

One of the objectives of Leg 33 was to decipher the history of vertical motion along the Line Islands chain by studying the stratigraphic distribution of shallow water debris brought to the drill sites by gravity flow of sedimentary material. At all three sites, reworked fossils of shallow water origin indicate that near-surface carbonate banks had become established synchronously along the chain by Campanian-Maestrichtian time, probably between 70 to 80 m.y. (see Figure 2, Unit 4). Interpretation of the history of these carbonates is critical to an analysis of the history of the chain in general because their presence places constraints on arguments involving the sequence of volcanism along the chain,

The original interpretation, by the shipboard party (Schlanger, Jackson, et al., 1974) of the cessation of volcanism ages, or "minimum basement ages," along the chain is shown in Figure 3. These ages were based on currently accepted zonal boundaries of the oldest fossils recovered and extrapolations to basement using reasonable accumulation rates. At Site 165 the oldest fossils found were of the E. eximus Zone, dated at 76-80 m.y. Between this zone and the lowermost basalt lay approximately 50 meters of sediment; the exact distance to basement used depends on an interpretation of where in the core barrel interval the deepest fossiliferous stratum and basalt was actually cut. Using a sediment accumulation rate of $15 \mathrm{~m} / \mathrm{m} . \mathrm{y}$., which we feel is a conservatively slow one, considering the debris-flow lithology of Unit 4 , the minimum basement age for the lowermost postedifice basanite cored at Site 165 would be 79 to 83 m.y. At Site 315, using the same logic and an age of 80-87 $\mathrm{m} . \mathrm{y}$. for the $M$. furcatus Zone and $15 \mathrm{~m} / \mathrm{m}$.y. as an accumulation rate for the 70 meters of sediment between it and the oceanic island type basalt, a minimum basement age of 85 to 92 m.y. can be obtained (shipboard analysis of the problem was based on an age of $80 \mathrm{~m} . \mathrm{y}$. for the $T$. aculeus- $M$. furcatus boundary, which yielded a minimum basement age of 85 m.y.). The K/Ar date obtained on these oceanic island basalts (Lanphere and Dalrymple, this volume) is $91.2 \pm 2.7$ m.y. At Site 316, basement was not reached but a stratigraphic argument, based on the lack of Unit 5 at the site, indicates that a considerable thickness of undrilled sediment may have lain below the bit when drilling stopped in the $T$. aculeus Zone at 77-80 m.y. and suggests a minimum basement age of 81-83 m.y. (see Martini, this volume, for a detailed discussion of the zonal age assignments).

Lanphere and Dalrymple (this volume) propose that the deepest volcanic rocks drilled at Site 165 could be as old as 100 m.y. This date taken together with the 91.2 \pm 2.7 m.y. date at Site 315 (and the lack of a K/Ar basalt date for Site 316) led them to argue for a possible age difference of as much as 12 m.y. between Sites 165 and 315 , thus allowing an age progression along the chain consonant with the postulated "hot spot" origin of the Wilson-Morgan type for the Line Islands. While we doubt the slowest extrapolation rate of Lanphere and Dalrymple (this volume) to the deepest potassic basanite drilled in Hole 165A, we think it entirely possible that the true Line Islands edifice age in this area may indeed be as old as 104 m.y., based on a volcanic progression rate of $5.2 \mathrm{~cm} / \mathrm{yr}$. Such basalts, of the oceanic island type, presumably underlie the deepest post-edifice type potassic basanites cored in Hole 165A.

Attempts to explain the synchronous development of shallow-water carbonate banks along the $1300-\mathrm{km}$-long segment of the Line Islands chain spanned by Sites 165 , 315 , and 316 , in terms of a Wilson-Morgan melting anomaly model, lead to serious difficulties. If the main edifice construction ceased as long ago as 104 m.y. at Site 165 , a time gap of some 20 to 30 m.y. existed before the onset of the development of the very shallow-water to reefal carbonate banks. As Dana (1849) pointed out over a century ago, islands along linear chains such as those of the Hawaii-Midway trend exhibit a degree of subsidence proportional to their distances from the active eruptive center. According to Dana's model, which is certainly still applicable, the seamounts near enough to Site 165 to have supplied the shallow-water skeletal debris would have sunk beneath the photic zone between 104 m.y. and 70-80 m.y., which marks the onset of bank development. Between 110 and 85 m.y. sea level was rising rapidly from +200 meters to +520 meters relative to present sea level (Hays and Pitman, 1973). Between the rising sea level and the cooling, subsiding seamount tops near Site 165 the gap to the photic zone was widening too rapidly for reef growth to occur. The rise in sea level between 110 and 85 m.y. has been cited as the prime cause for the drowning, in AlbianCenomanian time, of the formerly widespread rudistidrich reefs that once characterized the western Pacific seamount provinces (Matthews et al., 1974). Sea level did fall somewhat between 80 and 70 m.y. (Hays and Pitman, 1973) to a point 350 meters above present sea level. However, the Site 165 area would have by this time been too deep for reefal development to have occurred.

A geologically more reasonable explanation for the synchronous development of reefal conditions is that an 80-85 m.y. epeirogenic pulse affected the chain along its entire length, or at least that segment spanned by Sites 165 to 316 . We postulate that the Line Islands un- 


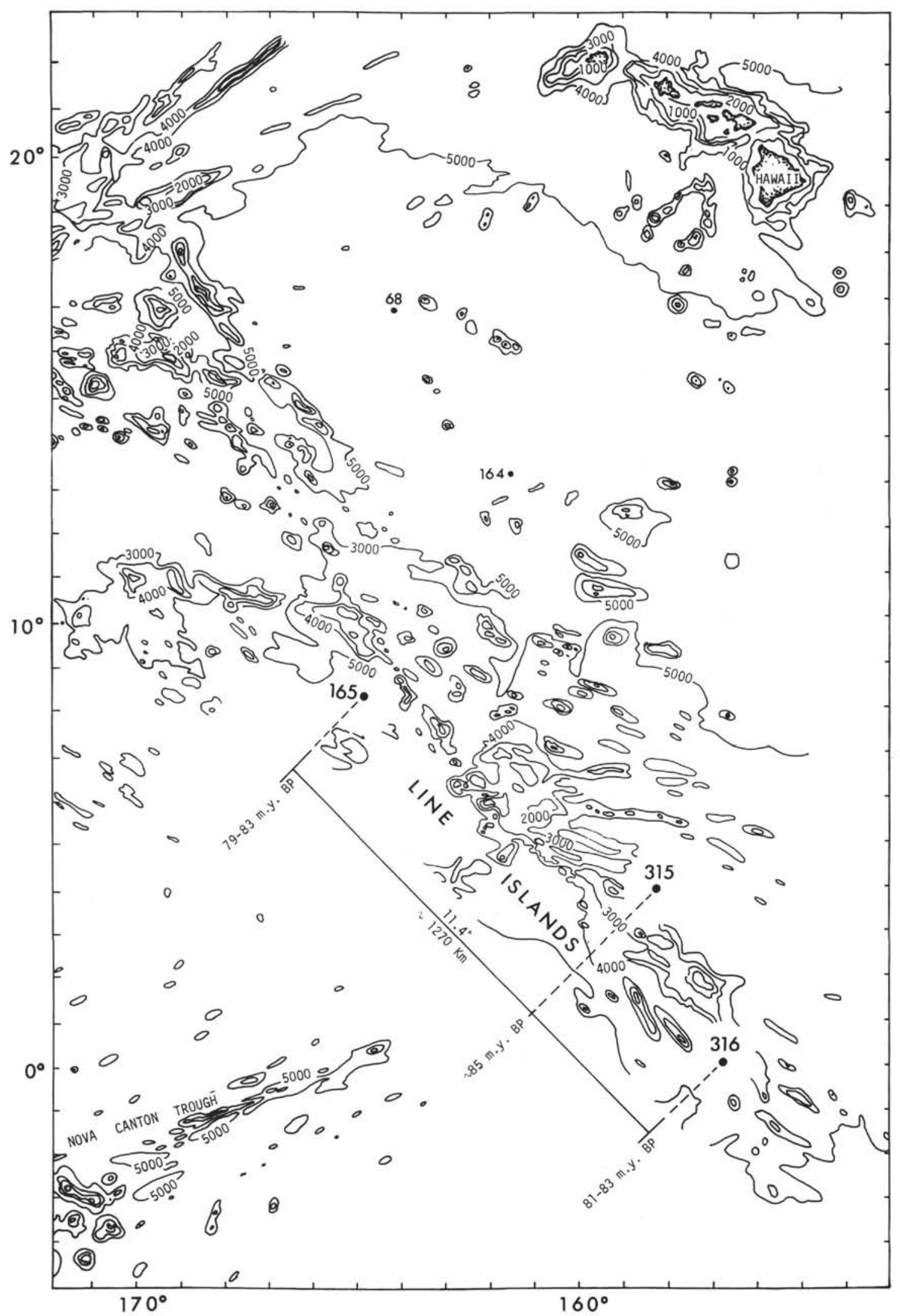

Figure 3. Map showing probable age of uppermost basalt flows along the Line Islands chain as determined by drilling at DSDP Sites 165,315 , and 316. 
derwent uplift as a result of the onset of a thermal event that caused the outbreak of post-edifice, for the most part potassic undersaturated basalts, and which ceased about 80-85 m.y. As a result of this uplift, many surfaces were raised into the shallow-water photic zone and the growth of carbonate banks was initiated all along the chain. During the slow subsidence that ensued on the cooling of the basement along the chain, certain reefs kept up with the pace of subsidence, producing the present-day Kingman Reef, and Palmyra, Washington, Fanning, and Christmas islands.

A similar mechanism was used by $\mathrm{Hsu}$ and Schlanger (1968) to explain the vertical tectonic history of "linear mobile belts" in the Pacific Basin. They proposed that the history of vertical motion of an area could be explained in terms of changes in the thermal state of the underlying crust and mantle that accompany volcanic events. As they pointed out (1968, p. 103): "Thus, an uplifted oceanic rise will not simply disappear when its underlying mantle reverts to its normal density state; the linear belt will become a guyot-atoll ridge which still stands high above surrounding ocean floors after a long subsidence history because of the isostatic effect of a thickened crust."

In summary, the best information we have at hand suggests that the Line Islands chain began to form some $128 \mathrm{~m} . \mathrm{y}$. on oceanic ridge tholeiitic crust west of that segment of the Pacific-Farallon Ridge between the Molokai and Clarion fracture zones just south of the Molokai Fracture Zone. South of the Clarion Fracture Zone, the ridge may well have paralleled the future position of the Line Islands chain as Winterer (this volume) suggests. The Line Islands chain apparently progressively propagated in a direction of $\$ 37.5^{\circ} \mathrm{E}$ at an average rate of about $5.2 \mathrm{~cm} / \mathrm{yr}$ along en echelon edifices built of materials much like those of the Samoan and Hawaiian chains. The morphology of the chain between its present position from $15^{\circ} \mathrm{N}$ to $6^{\circ} \mathrm{N}$ was modified by westnorthwest cross-structures. Oceanic island type volcanism along the chain between Sites 165 and 316 progressively ceased during the period $105-80$ m.y. The hypothesis of Morgan (1972) that the Line Islands are coeval with the Emperor and Marshall-Gilbert-Ellice chains is incorrect, as noted by Clague and Jarrard (1973), although the Line Islands could have formed about an older, more easterly pole than the more northerly trending chains. Present information does not disprove that the chain propagated at a regular rate as required by the Morgan (1972) hypothesis. The suggestion by Winterer (this volume) that the chain formed by a clutch of melting anomalies moving east-southeast and terminating on an abandoned Phoenix-Pacific ridge is an unnecessarily complex model in conflict with some data such as the morphology of the area between the southern Line Islands and the Marshall Islands (Figure 1), and the absence of Cretaceous magnetic lineations north and east of the Line Islands. Cockerham and Jarrard (this volume) have determined a $13.3^{\circ}$ northward component of drift for the Line Islands over the last 85 m.y. Therefore, immediately subsequent to the cessation of shield building volcanism, the southern Line Islands resided in the equatorial belt, and one can only conclude from the lack of corralline debris in sedimentary Unit 5 that the ancestral (>85 m.y.) Line Islands chain was a seamount chain whose summits nowhere projected into the photic zone. Epeirogenic uplift accompanied by eruptions of post-edifice, largely potassic basanites and nephelenites during the period 80-85 m.y., resulted in the appearance of reefal and shallow-water skeletal debris in sedimentary rocks 70-80 m.y. old. By approximately 65 m.y., volcaniclastic and reefal sedimentation waned, and pelagic sedimentation became dominant on the flanks of those edifices that were able to sustain coralline caps to the present time.

\section{TUAMOTU ISLANDS}

Very little new information has accrued on the Tuamotu chain beyond that given in the shipboard site report. Jackson et al. (this volume) confirmed the oceanic island character of the basaltic pebbles in Core 10 of Hole 318, and Beckmann (this volume) examined the larger foraminifers, bryozoans, mollusks, and coralline material in Hole 318 and found them to be, as we suspected, redeposited shallow-water fossils ranging in age from Eocene to Plio-Pleistocene. Martini (this volume) reexamined the nannofossils at the base of the hole and reaffirmed their belonging in Zone NP13, which according to the time scale used in this volume dates the oldest rock penetrated at 49-51 m.y. This age is the same as that of the deepest rocks penetrated at Site 76 (Hays et al., 1972). Drilling at neither Site 318 nor 76 penetrated basalt, and we can only say that at both sites the sedimentary rocks penetrated show evidence that nearby edifices composed of oceanic island type basaltic rocks formed, were eroded, and were subsequently capped by coral reefs as early as 49-51 m.y. If one projects the tenuous Line Islands rate of volcanic progression to Morgan's (1972) Line Islands-Tuamotu "bend," the projected age of that bend is 54 m.y., and further projection at the same rate to Site 318 yields an age of 46 m.y. for the cessation of volcanism. The HawaiianEmperor bend is now firmly dated at $42.3 \pm 1.6 \mathrm{~m} . \mathrm{y}$. (Clague et al., 1975) and bathymetry in the southernmost Line Islands leaves it far from clear that they extrapolate to an early Eocene "bend" with the Tuamotus, as proposed by Morgan (1972). Furthermore, the age of such a bend, if it exists, would predate the HawaiianEmperor bend by about $8 \mathrm{~m} . \mathrm{y}$. based on fossil ages at Site 318 or by 11 m.y. by extrapolation. No possibility exists that the bends are coeval as Morgan (1972) suggested.

Recent work further south in the Tuamotus suggests that they represent a complex of irregularly progressive chains that more or less fit Morgan's (1972) Hawaiian pole of rotation. Duncan et al. (1975) have dated Pitcairn Island at $0.45 \pm 0.2$ and $0.95 \pm 0.2 \mathrm{~m} . \mathrm{y}$. and have suggested that a progressing linear chain extends from Pitcairn through the Gambier Islands, through Mururoa atoll and into the Duke of Gloucester Islands. Using age data available at that time, they arrived at an average rate of volcanic propagation of about $11 \mathrm{~cm} / \mathrm{yr}$. Recent isochron normalized ages for Makapu, Aukena, and Mangareva islands of the Gambier group of 4.77 \pm 0.2 m.y. to $5.98 \pm 0.2$ m.y. have been given by Bellon (1974). Combining these ages with that of $7.0 \pm 1$ m.y. 
given by Chevallier (1973) for Mururoa Island gives an irregular rate of volcanic propagation for that part of the chain. The rate from Pitcairn Island to the Gambier Islands is $11 \mathrm{~cm} / \mathrm{yr}$, the rate from the Gambier Islands to Mururoa is $42 \mathrm{~cm} / \mathrm{yr}$, and the "average" rate along this proposed chain is $16 \mathrm{~cm} / \mathrm{yr}$. If one extrapolates from Mururoa to Site 318, one obtains a rate of volcanic progression of only $2.4 \mathrm{~cm} / \mathrm{yr}$ (Jackson, in press). It seems likely that although the Tuamotu chain lies roughly about Morgan's (1972) Hawaiian pole position, is composed of rocks of similar volcanic types, and grew during a part of the same time span, that it is a complex of shorter subchains and not a single unit characterized by the uniform progression required by Morgan's (1972) model.

\section{Manihiki Plateau}

Prior to drilling at Site 317, a number of oceanographic expeditions from Scripps Institution of Oceanography, Lamont-Doherty Geological Observatory, Woods Hole Oceanographic Institution, and the Hawaii Institute of Geophysics had conducted geological and geophysical investigations over the Manihiki Plateau. This information was summarized and interpreted by Winterer et al. (1974) and used as a basis for our precruise planning. The plateau is an anomalously high area surrounded by deep basins and capped by a thick section of sediment that shows a very well developed internal acoustic stratigraphy. Winterer et al. (1974) give details on the topography and general structural setting. According to these authors the plateau owes its origin to large outpourings of lava along now-abandoned spreading ridges, trapped on the Pacific plate, that were active in Barremian to Albian time near the junction of the Farallon, Pacific, and Antarctic plates (Figure 4; see also fig. 14 of Winterer, this volume).

The results obtained at Site 317 essentially confirmed the Winterer et al. (1974) interpretation of the origin of the plateau. K/Ar dating of the basement basalt gives a minimum age $106 \pm 3.5$ m.y. (Lanphere and Dalrymple, this volume), which is concordant with the fossil data. The oldest microfossil age is 107 m.y. near the lower/upper Aptian boundary. Kauffman (this volume) identified molluscs of Cretaceous age in Core 13, which is considered Aptian by microfaunal criteria. Kauffman found genera suggesting an early Cretaceous ageValanginian through Albian (probably pre-Albian). These data, taken together with the fact that the 106 \pm 3.5 m.y. K/Ar is a minimum age and the fact that 240 meters of volcaniclastic sediment lie between the deepest fossils and basalt, suggest a basement age of possibly 110-112 m.y. Data of Cockerham and Jarrard (this volume) indicate the high Manihiki Plateau was incorporated in the Pacific plate and was moving northward as long ago as $107 \mathrm{~m}$.y., and possibly as early as the age of the deepest basalts cored in Hole 317A.

The geological history of the Manihiki Plateau began therefore with the buildup of an apparently thick section of basalt of oceanic ridge tholeiite type, the extrusion of which ceased by approximately 110 m.y. The extreme vesicle size and abundance in the basalts cored at Site 317 indicate eruption in water less than 400 meters deep
(Jackson et al., this volume). ${ }^{1}$ Compositionally, they resemble the basalts cored below the Ontong-Java Plateau on Leg 30 (Andrews, Packham, et al., in press). Rocks dredged from around the plateau edges are also oceanic ridge tholeiite (Clague, this volume), but differ from those drilled at Site 317 in vesicularity and composition; they are less vesicular are are interpreted as having formed by a relatively large degree of partial melting at shallow depths. In addition, a gabbroic cumulate was dredged within the Danger Island Trough, one of the northeast-trending deep narrow troughs that cut the Manihiki Plateau (Winterer et al., 1974) which suggests that the troughs were sites of faulting and that a portion of Layer 3 was sampled by the dredge (Clague, this volume). The sedimentary history based on Site 317 results has been developed by Jenkyns (this volume). The oldest sediments are volcaniclastics derived from explosive hyaloclastite eruptions and weathering of volcanic products. Much of the material has been redeposited. The development of a geothermal system led to circulation of iron-bearing cupriferous solutions through the volcaniclastics, depositing iron oxidehydroxides and native copper. Kauffman (this volume) interprets the molluscan fauna in the upper parts of the volcaniclastic section as indicative of colonization of the shallow plateau as the water cleared. Water depths at this time were less than 200 meters, and the fauna indicates that a tropical to warm temperature regime prevailed. Paleomagnetic analyses by Cockerham and Jarrard (this volume) of the sedimentary section indicate that the plateau has moved $18.7^{\circ}$ northward since Late Cretaceous time. Taking into account the present latitude of $11^{\circ} \mathrm{S}$ for the plateau, the Late Cretaceous paleolatitude would have been nearly $30^{\circ} \mathrm{S}$, and this may well account for the apparent lack of reefal conditions near the drill site. If this explanation for the lack of reefal conditions is correct, then parts of the rim of the plateau must have been subaerial when volcanism ceased in order that reefs could have become established as the plateau moved northward through Cenozoic time. The fact that Suvarov, Danger, Nassau, Rakahanga, and Manihiki islands are present at all indicates that coral growth has kept up with the post-Cretaceous subsidence that characterized the later history of the plateau. At Manihiki atoll seismic refraction studies show that a probable coral limestone section 500 meters thick lies below the atoll (Hochstein, 1967).

The Cenozoic history of the plateau has been characterized by continual subsidence, allowing accumulation of over 500 meters of pelagic sediments. By the end of Eocene time the siliceous contribution waned and the Oligocene to recent deposits are very pure carbonates. Sediment accumulation rates (uncorrected for compaction) have varied but generally increased from 5 $\mathrm{m} / \mathrm{m} . \mathrm{y}$. in Oligocene time to $15 \mathrm{~m} / \mathrm{m} . \mathrm{y}$. in late Miocene to Pliocene time. This increase in sedimentation may reflect the northward motion of the plateau into more fertile waters. The chemical data of Donnelly and

\footnotetext{
'Mineralogy and magnetic data on the magnetic phases in these basalts also indicate a shallow water or subaerial origin (R.S. Cockerham, personal communication, September 1975).
} 

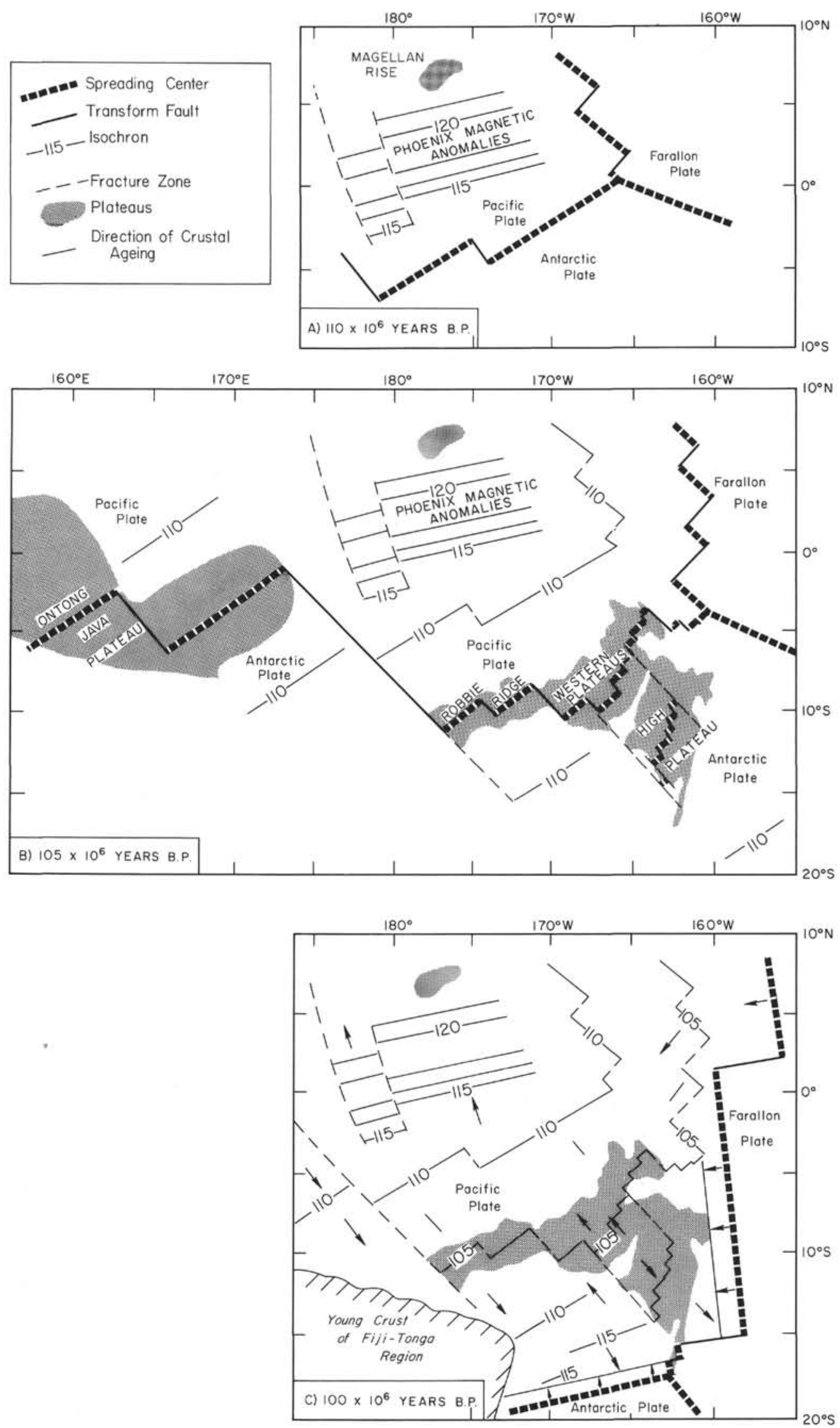

Figure 4. Initiation and early volcanic growth of the Manihiki Plateau (from Winterer et al., 1974). 
Wallace (this volume) point to the remarkably pure $\mathrm{CaCO}_{3}$ composition of the upper 360 meters of the plateau sediment cap. The total amount of subsidence since the cessation of oceanic ridge volcanism amounts to several kilometers; much of the high plateau is now between 2500 and 3000 meters deep and the volcanic basement lies approximately 1000 meters below that depth, yielding a total subsidence of 3500 to 4000 meters relative to present sea level.

Before the end of Cretaceous time, a sedimentological event of interest took place. In Core 16 a thin stratum (Section 2 at $133 \mathrm{~cm}$ ) with very high organic carbon values of $28.7 \%$ and $30.4 \%$ was found. These black, waxy carbonaceous clays are similar to sediments of Aptian/Barremian to Cenomanian age cored at Sites 101 and 105 in the Atlantic (Hollister, Ewing et al., 1972) on DSDP Leg 11. There, the black clays are highly carbonaceous and contain abundant pyrite. At Site 317, Core 16 was cut approximately 40 meters below sediments dated at 107 m.y.B.P. Thus, the carbonaceous clays at the Manihiki Plateau site are probably also Aptian/Barremian in age. Lancelot et al. (1972) studied the composition of the carbonaceous black clay layer cored at Sites 101 and 105, and came to the conclusion that "Stagnation in the whole North American Basin, and probably in the deepest parts of the entire North Atlantic characterized most of the early Cretaceous." The correlation of the carbonaceous clays between Sites 101 and 105 and Site 317 raises the interesting possibility that this Early Cretaceous carbonaceous event may have been a very widespread, perhaps worldwide oceanographic phenomenon.

Based on a study of reflector sequences within postEocene pelagic carbonate sections in the equatorial Pacific at Sites 64, 72, and 167, Schlanger and Douglas (1974) argued that certain reflectors could be correlated over the area represented by these three sites. According to their diagenetic model for the carbonate ooze-chalklimestone transition, certain strata have a high diagenetic potential and become cemented more quickly and thoroughly than adjacent ones with low diagenetic potentials; the interfaces between differentially cemented strata form reflectors. The diagenetic potential is a function of the foraminifer to coccolith to discoaster ratios in the sediment after initial burial. The foraminifer tests and coccolith elements contribute carbonate by dissolution, which precipitates as cement on discoasters; the implication being that a high foraminifer content in a buried stratum will hasten cementation. Broecker (1971) has shown that for the equatorial Pacific the amount of planktonic foraminifer test material measured as planktonics per gram of sediment was higher during the last glacial stage than during the last interglacial stage. Thus, sediments deposited during glacial maxima should have a higher diagenetic potential than sediments deposited in an interglacial stage. Schlanger and Douglas noted that their "a," "b," "c," and " $\mathrm{d}$ " reflectors correlate with glacial maxima or periods of oceanic cooling and are 3,5-6, 12-14 and 2126 m.y. old, respectively; their "e" reflector represents the top of the Eocene chert section at 43-44 m.y. The "b," "c," "d," and "e" reflectors could be identified because of the continuous coring program carried out in the upper part of the hole. The ages of these reflectors at Site 317 are 5-6, 12, 21 and 41-47 m.y. B.P., respectively (Figure 5), and fit the predicted ages quite well.

\section{REFERENCES}

Andrews, J.E., Packham, G., et al., in press. Initial Reports of the Deep Sea Drilling Project, Volume 30: Washington (U.S. Government Printing Office).

Baldwin, B., Coney, P.J., and Dickinson, W.R., 1975. Dilemma of a Cretaceous time scale and rates of sea-floor spreading: Geology, v. 1, p. 267-274.

Bass, M.N., Moberly, R., Rhodes, J.M., and Shih, C., 1973. Volcanic rocks cored in the central Pacific, Leg 17, Deep Sea Drilling Project. In Winterer, E.L., Ewing, J.E., et al., Initial Reports of the Deep Sea Drilling Project, Volume 17: Washington (U.S. Government Printing Office), p. 429 503.

Bellon, H., 1974. Historie geochronometrique des isles Gambier: Cahiers du Pacifique, v. 1, p. 245-251.

Broecker, W.S., 1971. Calcite accumulation rates and glacial to interglacial changes in oceanic mixing. In Turekian, K.K. (Ed.), Late Cenozoic glacial ages: New Haven, Yale Univ. Press, p. 240-265.

Chase, T.E., Menard, H.W., and Mammerickx, J., 1971. Topography of the North Pacific: Geol. Data Center, Scripps Inst. Oceanogr., Inst. Mar. Resources, Composite of Charts 1-10.

Chevallier, J.P., 1973. Geomorphology and geology of coral reefs in French Polynesia. In Jones, O.A. and Endean, R. (Eds.), Biology and geology of coral reefs: New York, (Academic Press), v. 1, Geology, p. 113-141.

Clague, D.A., 1974. The Hawaiian-Emperor seamount chain: its origin, petrology, and implications for plate tectonics: Unpublished Ph.D. thesis, Univ. of Calif. at San Diego.

Clague, D.A. and Jarrard, R.D., 1973. Tertiary Pacific plate motions deduced from the Hawaiian-Emperor chain: Geol. Soc. Am. Bull., v. 84, p. 1135-1154.

Clague, D.A., Dalrymple, G.B., and Moberly, R., 1975. Petrography and $\mathrm{K} / \mathrm{Ar}$ ages of dredged volcanic rocks from the western Hawaiian Ridge and the southern Emperor chain: Geol. Soc. Am. Bull., v. 86, p. 991-998.

Dana, J.D., 1849. Geology, Volume 10 of the United States Exploring Expedition during the years 1838-39, 1840, 1841, 1842: Philadelphia (G. Sherman and Co.).

Denoufbourg, G., 1965. Notice explicative sur la feuille Tahiti: Bur. Res. Géol. Miner., Paris.

Duncan, R.A., McDougall, I., Carter, R.M., and Coombes, D.S., 1975. Pitcairn Island-another Pacific hot spot? Nature, v. 251 , p. 679-682.

Dymond, J. and Windom, H.L., 1968. Cretaceous K-Ar ages from Pacific Ocean seamounts: Earth Planet. Sci. Lett., v. 4, p. 47-52.

Fischer, A.G. et al., 1971. Initial Reports of the Deep Sea Drilling Project, Volume 7: Washington(U.S. Government Printing Office).

Hawkins, J.W., Jr., and Natland, J.H., 1975. Nephelinites and basanites of the Samoan linear volcanic chain: Earth Planet. Sci. Lett., v. 24, p. 427-439.

Hays, J.D., et al., 1972. Initial Reports of the Deep Sea Drilling Project, Volume 9: Washington (U.S. Government Printing Office).

Hays, J.D. and Pitman, W.C., III, 1973. Lithospheric plate motion, sea level changes and climatic and ecologic consequences: Nature, v. 246, p. 18-22.

Heezen, B.C., Matthews, J.L., Catalano, R., Natland, J.H., Coogan, A., Tharp, M., and Rawson, M., 1973. Western Pacific Guyots. In Hee 

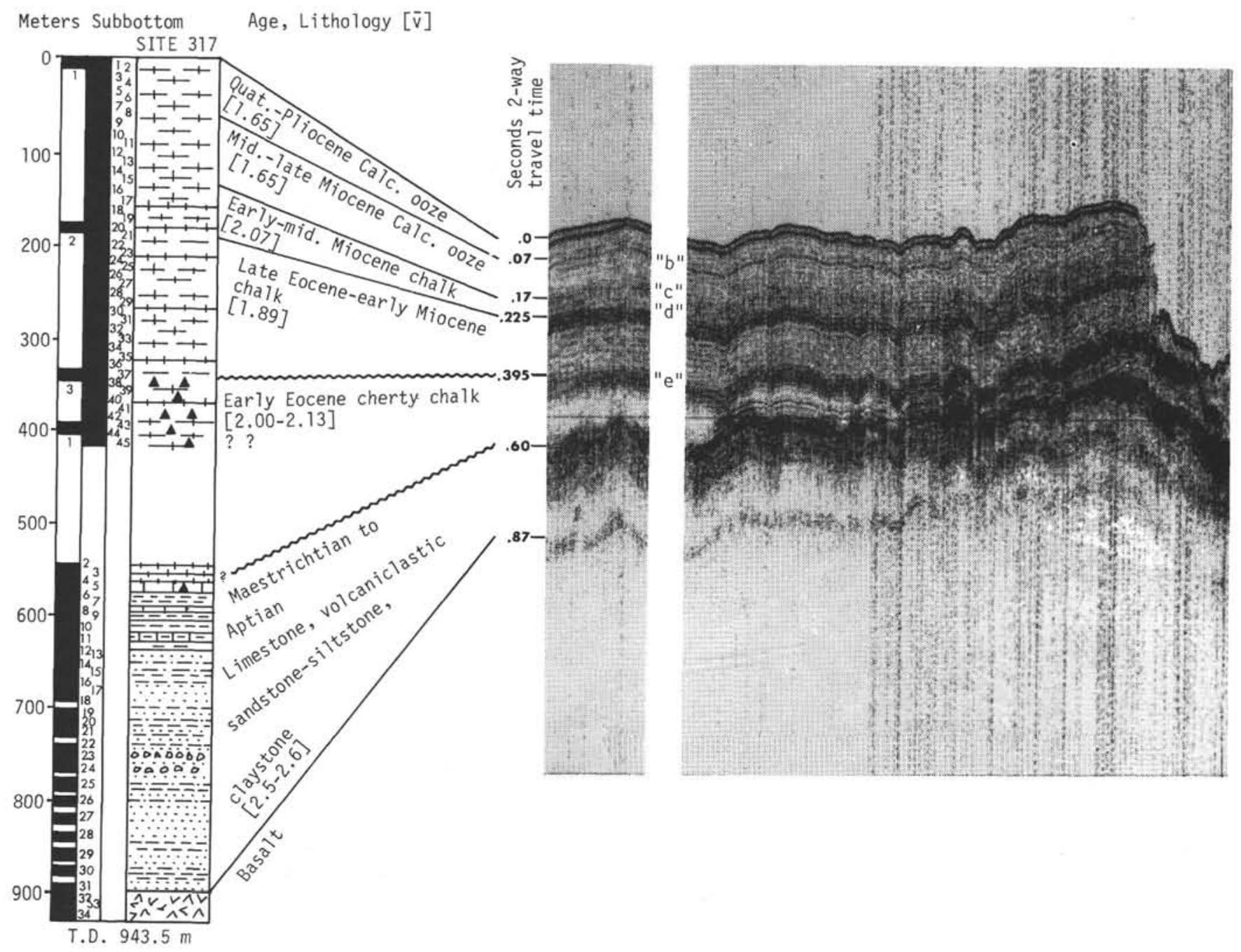

Figure 5. Correlation of reflectors at Site 317 with the " $b$, , “c," “d," and " $e$ " reflectors of Schlanger and Douglas (1974).

Washington (U.S. Government' Printing Office), p. 653-724. Heirtzler, J.R., Dickson, G.O., Herron, E.M., Pitman, W.C., III, and Le Pichon, X., 1968. Marine magnetic anomalies, geomagnetic field reversals, and the motions of the ocean floor and continents: J. Geophys. Res., v. 73, p. 2119-2136.

Hilde, T.W.C., Isezaki, N., Wageman, J.M., and Sclater, J.G., 1974. Mesozoic sea-floor spreading in the north Pacific (abstract): Program with Abstracts, Internat. Woollard Symposium, Hawaii Inst. Geophys., p. 18.

Hochstein, M.P., 1967. Seismic measurements in the Cook Islands, southwest Pacific Ocean: New Zealand J. Geol. Geophys., v. 10, p. 1499-1526.

Hollister, C.D., Ewing, J., et al., 1972. Initial Reports of the Deep Sea Drilling Project, Volume 11: Washington (U.S. Government Printing Office).

Hsü, K.J. and Schlanger, S.O., 1968. Thermal history of the upper mantle and its relation to crustal history in the Pacific Basin: Int. Geol. Congr., 22nd, Prague, v. 1, p. 91105.

Jackson, E.D., in press. Linear volcanic chains on the Pacific plate: Am. Geophys. Union Monogr., Geophys. Pacific Basin.

Lancelot, Y., Hathaway, J.C., and Hollister, C.D., 1972. Lithology of sediments from the North Atlantic, Leg 11, Deep Sea Drilling Project. In Hollister, C.D., Ewing, J., et al., Initial Reports of the Deep Sea Drilling Project,
Volume 11: Washington (U.S. Government Printing Office), p. 901-949.

Larson, R.L. and Chase, C.G., 1972. Late Mesozoic evolution of the western Pacific Ocean: Geol. Soc. Am. Bull., v. 83, p. 3627-3644.

Larson, R.L. Moberly, R., et al., 1974. Deep Sea Drilling Project, Leg 32: Geotimes, v. 16, p. 12-14.

Larson, R.L., Moberly R., et al., 1975. Initial Reports of the Deep Sea Drilling Project, Volume 32: Washington (U.S. Government Printing Office).

Larson, R.L. and Pitman, W.C., III, 1972. Worldwide correlation of magnetic anomalies, and its implication: Geol. Soc. Am. Bull., v. 83 , p. 3645-3663.

Macdonald, G.A. and Katsura, T., 1964. Chemical composition of Hawaiian lavas: J. Petrol., v. 5, p. 82-133.

Malahoff, A., Strange, W.E., and Woollard, G.P., 1966. Molokai fracture zone: Continuation west of the Hawaiian ridge: Science, v. 153, p. 521-522.

McBirney, A.R. and Aoki, K., 1968. Petrology of the island of Tahiti: Geol. Soc. Am. Mem. 116, p. 523-556.

Marshall, M., 1975. Petrology and chemical composition of basaltic rocks recovered on Leg 32, Deep Sea Drilling Project. In Larson, R.L., Moberly, R., Jr., et al., Initial Reports of the Deep Sea Drilling Project, Volume 32: Washington (U.S. Government Printing Office), p. 563-570. 
Matthews, J.L., Heezen, B.C., Catalano, R., Coogan, A., Tharp, M., Natland, J., and Rawson, M., 1974. Cretaceous drowning of reefs on Mid-Pacific and Japanese guyots: Science, v. 184 , p. $462-464$.

Moberly, R. and Heath, G.R., 1971. Volcanic rocks cored from the western and central Pacific: Leg 7, Deep Sea Drilling Project. In Winterer, E.L., Riedel, W.R., et al., Initial Reports of the Deep Sea Drilling Project, Volume 7: Washington (U.S. Government Printing Office), p. 10111026.

Morgan, W.J., 1972. Deep mantle convection plumes and plate motions: Geol. Soc. Am. Mem. 132, p. 203-213.

Myers, C.W., Bence, A.B., Papike, J.J., and Ayuso, R.A., 1975. Petrology of an alkali olivine basalt sill from Site 169 of DSDP Leg 17: The central Pacific basin: J. Geophys. Res., v. 80 , p. $807-822$.

Natland, J.H. and Clague, D.A., 1975. Comparison of Hawaiian and Samoan post-erosional volcanism (abstract): Geol. Soc. Am. Abstracts with Programs, v. 7, p. 354.

Ozima, M. and Saito, K., 1974. ${ }^{40} \mathrm{Ar} /{ }^{39} \mathrm{Ar}$ ages of some submarine rocks and their geophysical implications (abstract): Program with Abstracts, Internat. Woollard Symposium, Hawaii Inst. Geophys., p. 33.

Ozima, M., Saito, K., and Joshima, M., 1973. ${ }^{40} \mathrm{Ar}-{ }^{39} \mathrm{Ar}$ dating and magnetic studies of Leg 7 and Leg 17 basalt samples (abstract): EOS, Trans. Am. Geophys. Union, v. 54, p. 989.
Schlanger, S.O. and Douglas, R.G., 1974. The pelagic oozechalk-limestone transition and its implications for marine stratigraphy. Hsü, K.J. and Jenkyns, H.C. (Eds.), In Pelagic sediments on land and under the sea: Int. Assoc. Sedimentol., Spec. Publ. No. 1, p. 117-148.

Schlanger, S.O., Jackson, E.D., et al., 1974. Leg 33, Deep Sea Drilling Project: Testing a hot spot theory: Geotimes, v. 16, p. $16-20$.

van Andel, T.H., 1972. Establishing the age of the oceanic crust: Comm. Earth Sci., Geophys., v. 2, p. 157-168.

van Andel, T.H. and Bukry, D., 1973. Basement ages and basement depths in the eastern equatorial Pacific from Deep Sea Drilling Project, Legs 5, 8, 9, and 16: Geol. Soc. Am. Bull., v. 84, p. 2361-2370.

Vogt, P.R., Anderson, C.N., and Bracey, D.R., 1971. Mesozoic magnetic anomalies, sea-floor spreading and geomagnetic reversals in the southwestern north Atlantic: J. Geophys. Res., v. 76, p. 4796-4823.

Winterer, E.L., Riedel, W.R., et al., 1971. Initial Reports of the Deep Sea Drilling Project, Volume 7: Washington (U.S. Government Printing Office).

Winterer, E.L., Ewing, J.I., et al., 1973. Initial Reports of the Deep Sea Drilling Project, Volume 17: Washington (U.S. Government Printing Office).

Winterer, E.L., Lonsdale, P.F., Matthews, J.L., and Rosendahl, B.R., 1974. Structure and acoustic stratigraphy of the Manihiki Plateau: Deep-Sea Res., v. 21, p. 793-814. 